\title{
Aeropyrum pernix gen. nov., sp. nov., a Novel Aerobic Hyperthermophilic Archaeon Growing at Temperatures up to $100^{\circ} \mathrm{C}$
}

\author{
YOSHIHIKO SAKO,${ }^{1 *}$ NORIMICHI NOMURA, ${ }^{1}$ ARITSUNE UCHIDA, ${ }^{1}$ YUZABURO ISHIDA, ${ }^{1}$ \\ HIROYUKI MORII, ${ }^{2}$ YOSUKE KOGA, ${ }^{2}$ TOSHIHIRO HOAKI, ${ }^{3}+$ AND TADASHI MARUYAMA ${ }^{3}$ \\ Laboratory of Marine Microbiology, Department of Applied Bioscience, Graduate School of Agriculture, Kyoto \\ University, Kyoto 606-01, ${ }^{1}$ Department of Chemistry, School of Medicine, University of Occupational \\ and Environmental Health, Kitakyushu $807,{ }^{2}$ and Marine Biotechnology Institute,
} Shimizu Laboratories, Shimizu, Shizuoka $424,^{3}$ Japan

\begin{abstract}
A novel aerobic hyperthermophilic archaeon was isolated from a coastal solfataric vent at Kodakara-Jima Island, Japan. The new isolate, strain $\mathrm{K} 1$, is the first strictly aerobic organism growing at temperatures up to $100^{\circ} \mathrm{C}$. It grows optimally at 90 to $95^{\circ} \mathrm{C}, \mathrm{pH} 7.0$, and a salinity of $3.5 \%$. The cells are spherical shaped and 0.8 to $1.2 \mu \mathrm{m}$ in diameter. Various proteinaceous complex compounds served as substrates during aerobic growth. Thiosulfate stimulates growth without producing $\mathrm{H}_{2} \mathrm{~S}$. The core lipids consist solely of $\mathrm{C}_{25}$-isopranyl archaeol(glycerol diether). The $\mathrm{G}+\mathrm{C}$ content of the genomic DNA is $67 \mathrm{~mol} \%$. Phylogenetic analysis based on $16 \mathrm{~S}$ rRNA sequence indicates that strain $\mathrm{K1}$ is a new member of Crenarchaeota. On the basis of our results, the name Aeropyrum pernix gen. nov., sp. nov. is proposed (type strain: K1; JCM 9820).
\end{abstract}

Proposal of the Archaea (originally called archaebacteria) as a discrete domain $(57,58)$ shed new light on the central problems of both early evolution of life and prokaryotic systematics. Although this concept is now generally accepted because of the several biochemical features peculiar to the Archaea, it is still a matter of controversy how the Archaea domain is phylogenetically related to the other two domains, the Eucarya (eukaryote) and the Bacteria (eubacteria) (9).

This problem stems partially from an essential lack of information on the deepest (earliest) branches within the universal phylogenetic trees. For instance, a "deep missing branch" might decrease the reliability of the deep-branching topologies of the phylogenetic trees. In order to obtain additional information pertinent to this problem, we aimed to isolate organisms that might be representative of the deep missing branches.

Interestingly, it was pointed out that the deepest and shortest branches within the universal phylogenetic trees are dominated by hyperthermophiles, which grow optimally at temperatures above $80^{\circ} \mathrm{C}(1,2,3,55)$. During the past decade, many new hyperthermophiles were isolated from solfataric fields and submarine volcanic vents (43). Those include the hyperthermophilic methanogenic archaea, the archaeal sulfate reducers, the hyperthermophilic $\mathrm{S}^{0}$-metabolizers, and the genera Thermotogales and Aquifex within the Bacteria. However, since oxygen availability in the hydrothermal environments is low because of poor solubility, most studies of life in these ecosystems have been restricted to anaerobic organisms $(17,20)$.

Recently, we succeeded in the isolation and cultivation of a novel type of the strictly aerobic hyperthermophilic archaeon, growing optimally at temperatures above $90^{\circ} \mathrm{C}$. In this report, we characterize the new isolate and propose that it should be classified in a new genus, Aeropyrum.

* Corresponding author. Phone: 81-75-753-6218. Fax: 81-75-7536226. Electronic mail address: mmb@kais.kyoto-u.ac.jp.

$\dagger$ Present address: Biotechnology Research Department, Taisci Corporation, Narashino, Chiba 275, Japan.

\section{MATERIALS AND METHODS}

Collections of samples. Hot sedimentary materials and venting water were collected at a coastal solfataric thermal vent in Kodakara-Jima Island $\left(29^{\circ} 13^{\prime} \mathrm{N}\right.$, $129^{\circ} 20^{\prime}$ E) during a cruise of the rescarch vessel Sogen-maru in 1993. Anaerobic hyperthermophiles were isolated from this field $(16,17,28)$. In situ temperature was determined with a mercury-filled Celsius thermometer $\left(0\right.$ to $\left.200^{\circ} \mathrm{C}\right)$, and the $\mathrm{pH}$ was estimated by a $\mathrm{pH}$ meter (Toa Electronics, Tokyo, Japan). After collection, the samples were brought back to the laboratory, cooled on ice, and stored at $4^{\circ} \mathrm{C}$ until enrichment.

Culture conditions. The base for all media described in this paper is the synthetic seawater JS, which was prepared from Jamarine S synthetic sea salts (Jamarine Laboratory, Osaka, Japan) according to the manufacturer's instructions. Unless specified otherwise, the new isolate was grown in the standard medium referred to as JXT, containing (per liter of JS) $1 \mathrm{~g}$ of yeast extract (Difco Laboratories, Detroit, Mich.), $1 \mathrm{~g}$ of trypticase peptone (BBL Microbiology Systems, Cockeysville, Md.), and $1 \mathrm{~g}$ of $\mathrm{Na}_{2} \mathrm{~S}_{2} \mathrm{O}_{3} \cdot 5 \mathrm{H}_{2} \mathrm{O}$, pH 7.0 (adjusted with $\mathrm{HCl}$ at room temperature). For enrichment cultures and isolation, JX medium, prepared by omitting $\mathrm{Na}_{2} \mathrm{~S}_{2} \mathrm{O}_{3} \cdot 5 \mathrm{H}_{2} \mathrm{O}$ from JXT medium, was used.

Cultures were routinely grown in screw-capped test tubes (180 by $18 \mathrm{~mm})$ containing $10 \mathrm{ml}$ of medium and incubated at $90^{\circ} \mathrm{C}$ in a forced convection oven (FC-610; Advantec, Tokyo, Japan) without shaking. In order to maintain aerobic culture conditions, the gas phase of the closed test tubes was not evacuated and the atmospheric air $(100 \mathrm{kPa})$ was confined. Resazurin $(1 \mu \mathrm{g} / \mathrm{ml})$ was used as a redox indicator.

Batch cultures were grown in cotton-plugged 2-liter Erlenmeyer flasks containing $500 \mathrm{ml}$ of medium and incubated at $90^{\circ} \mathrm{C}$ in an air bath rotary shaker (RGS- 32.TT; Sanki Seiki, Osaka, Japan) with vigorous shaking (180 rpm).

Substrate utilization. In an attempt to find carbon substrates which would sustain growth and to test the optimum concentration for growth, each of the following organic substances (obtained from Nacalai Tesque, Kyoto, Japan, except where noted otherwise) was added to $10 \mathrm{ml}$ of the JS base, supplemented with $0.1 \%$ (wt/vol) $\mathrm{Na}_{2} \mathrm{~S}_{2} \mathrm{O}_{3} \cdot 5 \mathrm{H}_{2} \mathrm{O}$, in concentrations (wt/vol) of $0.05,0.1,0.2$, and $0.4 \%: \mathrm{D}-(-)$-ribose, L- $(+)$-arabinose, $\mathrm{D}-(+)$-xylose, $\mathrm{D}-(+)$-glucose, $\mathrm{L}-(-)$ glucose, $\mathrm{D}-(+)$-galactose, $\mathrm{D}-(-)$-fructose, $\mathrm{L}-(-)$-fucose, $\mathrm{L}-(+)$-rhamnose, $\mathrm{D}-(+)$ mannose, maltose, lactose, sucrose, $\mathrm{D}-(+)$-cellobiose, $\mathrm{D}-(+)$-melibiose, $\mathrm{D}-(+)-$ raffinose, cellulose, starch, D-sorbitol, D-mannitol, glycerol, acetate, alanine plus glycine, 20 different L-amino acids, yeast extract (Difco), tryptone (Difco), nutrient broth (Difco), Casamino Acids (vitamin free; Difco), and trypticase peptone (BBL). To test the various sulfur compounds, the $\mathrm{Na}_{2} \mathrm{~S}_{2} \mathrm{O}_{3}$ in JXT medium was replaced with $10 \mathrm{mM}$ (each) $\mathrm{Na}_{2} \mathrm{SO}_{4}, \mathrm{Na}_{2} \mathrm{SO}_{3}, \mathrm{~S}^{0}$, cysteine, or methionine. These cultures were incubated at $90^{\circ} \mathrm{C}$ without shaking.

Sulfide analysis. The sulfide production during growth was detected qualitatively as described by Huber et al. (19).

Oxygen requirement for growth. In order to ensure strict anaerobiosis, the anaerobic techniques described by Balch and Wolfe (4) were employed. Oxygen was reduced by adding $0.05 \%$ (wt/vol) $\mathrm{Na}_{2} \mathrm{~S} \cdot 9 \mathrm{H}_{2} \mathrm{O}$. Microaerobic culture conditions were achieved as described by Huber et al. (21) with minor modifications. Prior to autoclaving, $10 \mathrm{ml}$ of medium was dispensed into a $120-\mathrm{ml}$ glass bottle (Schott Glaswerke, Mainz, Germany) that was tightly sealed with butyl rubber 
stoppers, and the gas phase was exchanged with either $\mathrm{H}_{2}-\mathrm{CO}_{2}(80: 20,300 \mathrm{kPa})$ or $\mathrm{N}_{2}(100 \%, 300 \mathrm{kPa})$. In both experiments, the state of oxygenation was monitored by resazurin $(1 \mu \mathrm{g} / \mathrm{ml})$, and cultures were incubated at $90^{\circ} \mathrm{C}$ without shaking.

Light and electron microscopy. Cells were inspected with a Nikon Optiphot XF-NT differential interference light microscope equipped with an oil immersion objective of $100 / 1.25$. Transmission electron microscopy of negatively stained cells was carried out as described by Zillig et al. (59). The cells were negatively stained with 1 to $2 \%(\mathrm{wt} / \mathrm{vol})$ uranyl acetate and observed in a Hitachi $\mathrm{H}-7000$ transmission electron microscope at an accelerating voltage of $75 \mathrm{kV}$. For ultrathin sectioning, cells were fixed in JXT medium with $2 \%$ (vol/vol) glutaraldehyde and postfixed with $1 \% \mathrm{OsO}_{4}$. The fixed cells were then dehydrated with ethano and embedded in Quetol 812 (Nisshin EM, Tokyo, Japan) epoxy resin. Thin sections were double contrasted with uranyl acetate and lead citrate. The spec imens were observed with a JEOL $1200 \mathrm{EX}$ II electron microscope operated at 80 $\mathrm{kV}$.

Determination of growth. Growth was determined either by measurement of the optical density at $660 \mathrm{~nm}\left(\mathrm{OD}_{000}\right)$ or by direct cell counting by using a Thom chamber (depth, $0.02 \mathrm{~mm}$ ). A good correlation was found between these two methods in exponential and stationary phase cultures. In the standard culture conditions, an $\mathrm{OD}_{660}$ of 1 corresponded to a cell density of about $1.4 \times 10^{9}$ cells per $\mathrm{ml}$.

To study the growth characteristics, the batch culture technique described above was applied. At temperatures above $100^{\circ} \mathrm{C}$, screw-capped 1-liter glas bottles (Schott Glaswerke) were used to prevent the evaporation of the medium. The $\mathrm{pH}$ dependency of growth was studied in JXT medium with various buffer systems at a concentration of $20 \mathrm{mM}$, e.g., sodium succinate (below pH 5.0 ), MES [2-( $N$-morpholino) ethanesulfonic acid] ( $\mathrm{pH} 5.5$ to 6.5$)$, HEPES [N-(2 hydroxyethyl) piperazine- $N^{\prime}$-2-cthanesulfonic acid] (pH 7.0 to 8.0), and BTP \{1,3-bis [tris (hydroxymethyl) methylamino] propane\} ( $\mathrm{pH} 8.5$ or above). The $\mathrm{pH}$ of the medium was adjusted by the addition of $\mathrm{HCl}$ or $\mathrm{NaOH}$ at room temperature. Growth at different salinities was determined by using $2 \times$ JS diluted appropriately in the medium. Doubling times were calculated by using linear regression analysis from 3 to 5 points along the logarithmic part of the resulting growth curves.

Antibiotic sensitivity. Sensitivity to the antibiotics chloramphenicol, ampicillin, vancomycin, and cycloserine (all from Sigma Chemical, St. Louis, Mo.) was tested at a concentration of $100 \mu \mathrm{g} / \mathrm{ml}$. The temperature for these tests was $70^{\circ} \mathrm{C}$. Preliminary experiments with the bacterium Thermus aquaticus (ATCC 25104) had indicated that the antibiotics were effective at $70^{\circ} \mathrm{C}$.

Lipid analysis. Total lipid was extracted from the cells as described by Bligh and Dyer ( 8 ) and analyzed by two-dimensional thin-layer chromatography (2DTLC) performed on silica gel 60 plates (Art. 5721; Merck, Darmstadt, Germany) Solvents included chloroform-methanol-7 $\mathrm{M}$ aqueous ammonia $(65: 35: 8, \mathrm{vol}$ $\mathrm{vol} / \mathrm{vol}$ ) in the first dimension and chloroform-methanol-acetic acid-water (85 $30: 15: 5, \mathrm{vol} / \mathrm{vol} / \mathrm{vol} / \mathrm{vol}$ ) in the second dimension. Polar lipid composition was determined by measurement of the phosphorus (6) of individual lipid spots on the 2D-TLC chromatogram.

Core lipids were prepared by splitting off the polar head groups by acid methanolysis $\left(5 \% \mathrm{HCl}\right.$-methanol at $100^{\circ} \mathrm{C}$ for $\left.2 \mathrm{~h}\right)$ of the total lipid extracts and separated by TLC with the solvent light petroleum-diethyl ether-acetic acid $(50: 50: 1, \mathrm{vol} / \mathrm{vol} / \mathrm{vol})$. Hydrocarbon chains were prepared from the core lipids by hydroiodic acid degradation followed by $\mathrm{LiAlH}_{4}$ reduction as previously reported (31) and identified by gas chromatography-mass spectrometry and electron impact mass spectrometry employing instrumentation and conditions as previously described (33). The polar head groups obtained in the aqueous fraction of the acid methanolysis were further acid hydrolyzed $\left(1 \mathrm{M} \mathrm{HCl}\right.$ at $100^{\circ} \mathrm{C}$ for $3 \mathrm{~h}$ or $4 \mathrm{M} \mathrm{HCl}$ at $100^{\circ} \mathrm{C}$ for $16 \mathrm{~h}$ ) and acetylated. The acetylated hydrolysate was analyzed by gas liquid chromatography as described previously (31). Glycerophosphoric esters prepared from the total lipid extracts by dealkylation with $\mathrm{BCl}_{3}$ (32) were analyzed by cellulose TLC (Art. 5716, Merck) (32) with the solven phenol-water $(100: 38, \mathrm{vol} / \mathrm{vol})$. Authentic samples of archaeol and caldarchaeol (30) were prepared from total lipids of Methanobacterium thermoautotrophicum or Sulfolobus solfataricus.

DNA preparation. Cell pellets (about $1 \mathrm{~g}$ ) were suspended in $10 \mathrm{ml}$ of NET buffer ( $50 \mathrm{mM}$ Tris-HCl, $150 \mathrm{mM} \mathrm{NaCl}, 100 \mathrm{mM} \mathrm{Na}_{2}$-EDTA [pH 8.0]) containing $2 \%(\mathrm{wt} / \mathrm{vol}$ ) sodium dodecyl sulfate and $0.1 \mathrm{mg}$ of proteinase $\mathrm{K}$ (Nacala Tesque) per $\mathrm{ml}$ and incubated at $65^{\circ} \mathrm{C}$ for $30 \mathrm{~min}$. The crude genomic DNA was prepared by the method of Sambrook et al. (38) and was purified by a protoco which employed cetyltrimethyl ammonium bromide (29) and by $\mathrm{CsCl}$ densitygradient centrifugation.

DNA base composition. The $\mathrm{G}+\mathrm{C}$ content of the genomic DNA was determined by high-performance liquid chromatography (27) with a DNA-GC kit (Yamasa Shoyu, Tokyo, Japan). Calf thymus DNA (42 mol\% G+C; Sigma) (26) and nonmethylated DNA from bacteriophage $\lambda(49.8 \mathrm{~mol} \% \mathrm{G}+\mathrm{C}$; Takara Shuzo, Kyoto, Japan) (39) were used as references.

16S rRNA preparation. 16S rRNA was prepared essentially according to Traub et al. (47) with modifications as follows. The exponentially growing cells (about $1 \mathrm{~g}$ ) were suspended in $20 \mathrm{ml}$ of buffer I $[10 \mathrm{mM}$ Tris- $\mathrm{HCl}, 10 \mathrm{mM}$ $\mathrm{Mg}\left(\mathrm{CH}_{3} \mathrm{COO}\right)_{2}, 60 \mathrm{mM} \mathrm{NH} \mathrm{Cl}_{4}, 6 \mathrm{mM} 2$-mercaptoethanol, pH 7.8] and $20 \mathrm{ml}$ of glass beads (type I; Sigma) was added. The suspension was vortexed for $15 \mathrm{~min}$ at $4^{\circ} \mathrm{C}$ and centrifuged twice at $30,000 \times g$ for $30 \mathrm{~min}$. The supernatant was removed and recentrifuged at $105,000 \times g$ for $6 \mathrm{~h}$ to precipitate the ribosomes. The pellet was resuspended in buffer I and treated with RNase-free DNase (Boehringer, Mannheim, Germany) at a concentration of $2 \mu \mathrm{g} / \mathrm{ml}$. rRNAs were obtained after three extractions with phenol-chloroform followed by two ethano precipitations and separated by a 5 to $20 \%$ sucrose density gradient centrifugation at $100,000 \times g$ for $17 \mathrm{~h}$ (TST 28.38 rotor; Kontron Instruments, Milan, Italy) Fractions containing $16 \mathrm{~S}$ rRNA were pooled. Purity of the $16 \mathrm{~S}$ rRNA was checked electrophoretically.

16S rRNA analysis. A cDNA clone of the 16S rRNA was obtained after reverse transcription and PCR amplification. The oligonucleotide 1521R (5'-A GGTGATTCAGCCGCAGGTT), complementary to the 3 '-tail conserved region of the archaeal $16 \mathrm{~S}$ rRNA, was employed to prime first-strand synthesis with Superscript II RNaseH ${ }^{-}$(GIBCO Laboratories, Grand Island, N.Y.). The reverse transcription reaction was performed according to the manufacturer's instructions, and the product was amplified by PCR with Arch21F ( $5^{\prime}$-TTCCG GTTGATCCYGCCGGA) (10) and $1521 \mathrm{R}$ as primers. Thirty-five amplification cycles of $90 \mathrm{~s}$ at $96^{\circ} \mathrm{C}, 1 \mathrm{~min}$ at $62^{\circ} \mathrm{C}$, and $2 \mathrm{~min}$ at $72^{\circ} \mathrm{C}$ were performed. The double-stranded PCR product was cloned directly into the pCRII vector (Invitrogen, San Diego, Calif.) to yield plasmid pNA4. The nucleotide sequence was determined by the dideoxy sequencing method $(40)$ by using a set of primer complementary to conserved regions located along the archaeal 16S rRNA. The sequence was aligned to a collection of archaeal 16S rRNA sequences (DNA Data Bank of Japan [DDBJ], National Institute of Genetics, Shizuoka, Japan). Numbers of base substitutions per site were estimated by the method of Tajima and Nei (45), and the phylogenetic tree was inferred on the basis of the neighborjoining method (36). The resulting tree was tested by using bootstrap analysis (14)

Nucleotide sequence accession number. The $16 \mathrm{~S}$ rRNA sequence of isolate $\mathrm{K} 1$ will appear in the DDBJ, EMBL, and GenBank nucleotide sequence databases with the accession number D83259.

\section{RESULTS}

Enrichment and isolation of the aerobic hyperthermophile. In order to enrich aerobic hyperthermophiles, $10 \mathrm{ml}$ of $\mathbf{J X}$ medium was inoculated with approximately $1 \mathrm{~g}$ of sample in the laboratory. The sample was a mixture of sandy sediment and clear seawater. Microbial mat material was not visible in the sample. The original temperature was 98 to $103^{\circ} \mathrm{C}$, and the $\mathrm{pH}$ was 6.9. The enrichment was performed at $90^{\circ} \mathrm{C}$ in screwcapped test tubes with air as the gas phase $(100 \mathrm{kPa})$ without shaking. Within 2 days, turbidity caused by cell growth was observed. This growth consisted of a mixed population of various sizes of rods and cocci. During this enrichment culture, resazurin remained red, and sulfide was not produced. All positive enrichment cultures could be successfully transferred in the same medium.

In order to obtain pure cultures, a dilution-to-extinction technique was employed (5). After the cell density of an enrichment culture reached approximately $10^{7}$ cells per $\mathrm{ml}, 5$ separate dilution series were conducted in which 5 1:10 dilutions of the culture were followed by 20 1:3 dilutions. Each dilution in the dilution-to-extinction series was carried out in triplicate and incubated for at least 7 days. The culture in the tube showing growth at the highest dilution was designated isolate $\mathrm{K} 1$, which usually grew up to about $10^{7}$ cells per $\mathrm{ml}$ in 4 days. The purity of this culture was routinely confirmed by microscopic examinations and by restriction fragment length polymorphism (RFLP) analysis of the PCR-amplified 16S rRNA gene fragment (data not shown). For further investigations, JX medium was replaced by JXT medium, in which a higher final cell density was obtained as described below. In this medium, the cell yield in batch culture was about $1 \mathrm{~g} / \mathrm{liter}$ (wet weight) in stationary phase. Packed cell masses exhibited a brown color.

Morphology. Cells of isolate K1 were irregular cocci with some sharp edges. The cell size was 0.8 to $1.0 \mu \mathrm{m}$ in diameter. The cells stained gram negative. They often appeared singly, but pairs were also observed (Fig. 1). Motility was observed under the light microscope in exponential and stationary phase cultures. Motility was strongly enhanced by heating the microscopic slide glass to $90^{\circ} \mathrm{C}$. The cells were frequently surrounded 


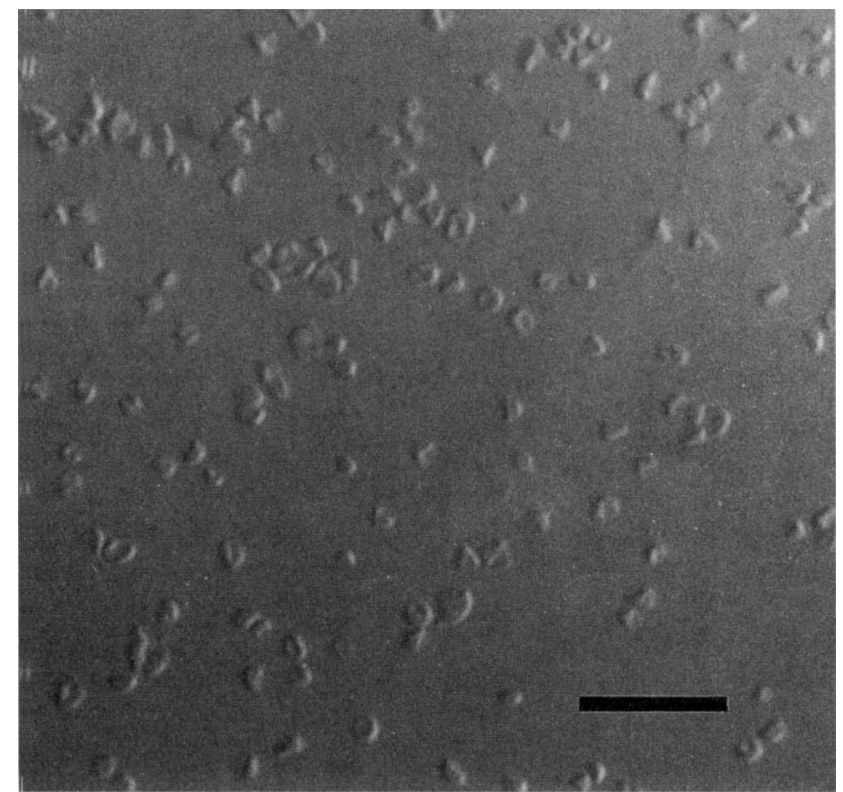

FIG. 1. Differential interference micrograph of Aeropyrum pernix K1 cells. Bar, $5 \mu \mathrm{m}$.

by pilus-like appendages (Fig. 2a). Flagella were not observed. When treated by a low osmotic shock, ghost cells of lower electron density were observed in some projections. They exhibited larger diameters than cells with high electron density and revealed a structure of the envelope (Fig. 2b). The cells were covered by a cell envelope (S-layer-like structure) about $25 \mathrm{~nm}$ wide outside the cytoplasmic membrane (Fig. 3). A typical subunit structure of the S-layer was not clearly discerned in this cell envelope. However, small areas of the cell envelope were sectioned at a shallow angle (margin of the cell appearing in the lower left corner of Fig. 3) and a faint repeating pattern was visible. Extracellular materials in sheets and small fragments shown in Fig. 3 might be the cell envelope and were present in the stationary phase cell pellet. Isolate $\mathrm{K} 1$ also had a dense layer just outside the cytoplasmic membrane, with a separate cell envelope spaced much further out from the cell. These structural features are different from the archaeal cell surfaces described to date (7).

Physiological characterization of growth. Isolate K1 was a heterotroph and grew only under aerobic culture conditions, indicating that isolate $\mathrm{K} 1$ grew by aerobic respiration. Both under microaerobic and strictly anaerobic conditions, growth was completely inhibited. The cells exposed to strictly anaerobic but not microaerobic conditions were rapidly inactivated and lysed. Growth did not resume even upon return to aerobic conditions. The microaerobic incubation merely prevented growth and did not kill cells. Maximum cell densities (up to $1.5 \times 10^{9}$ cells per $\mathrm{ml}$ ) were obtained by cultures incubated with shaking.

The new isolate was able to grow on proteinaceous complex substrates such as yeast extracts, trypticase peptone, tryptone, or nutrient broth but not on Casamino Acids. Yeast extract, trypticase peptone, and tryptone allowed growth at concentrations of 0.05 to $0.4 \%$. Yeast extract and trypticase peptone $(0.1 \%)$ were the most efficacious in supporting growth. A slight growth inhibition was observed with yeast extract, trypticase peptone, and tryptone at a $0.4 \%$ concentration. Nutrient broth
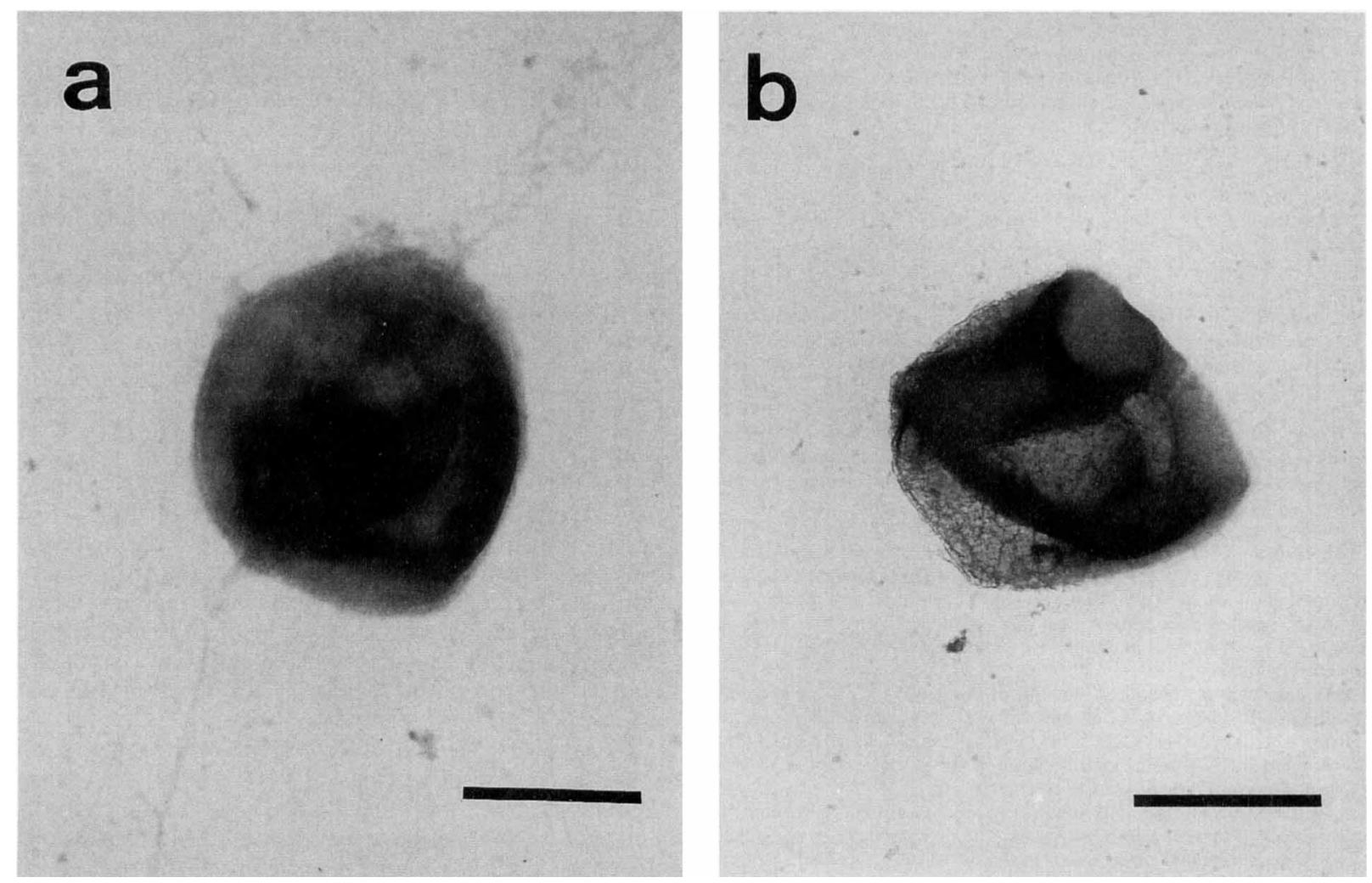

FIG. 2. Electron micrographs of Aeropyrum pernix K1. (a) Single cell with pili. (b) Ghost cell exhibiting a cell envelope. All cells were negatively stained with uranyl acetate. Bars, $0.5 \mu \mathrm{m}$. 


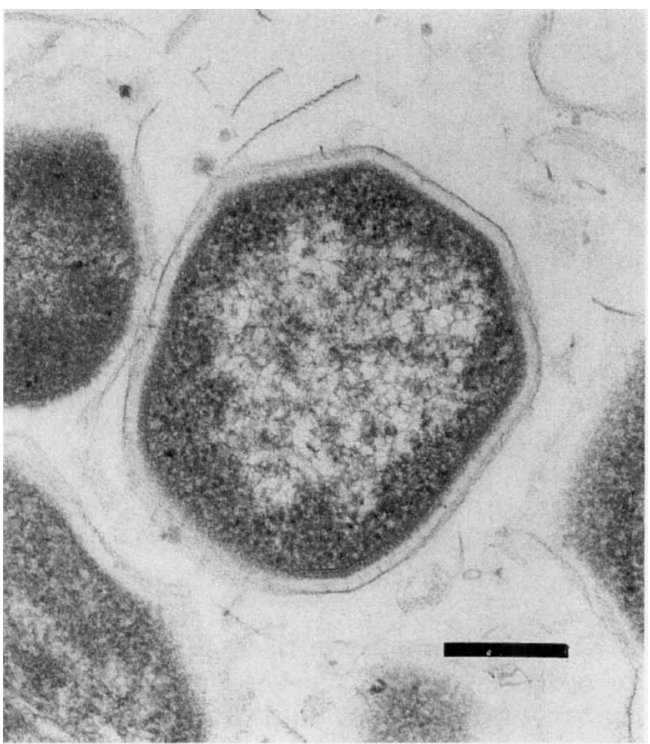

FIG. 3. Ultrathin section of Aeropynum pernix K1. Bar, $0.2 \mu \mathrm{m}$.

concentrations of over $0.1 \%$ inhibited growth. Any single carbohydrate, organic acid, or amino acid tested within the concentration range of 0.05 to $0.4 \%$ did not suffice as a sole carbon and energy source. The growth yield was stimulated about eightfold by thiosulfate. However, thiosulfate was not required for growth. $\mathrm{H}_{2} \mathrm{~S}$ was not formed during growth in either the presence or absence of thiosulfate. The growth yield was not stimulated by other sulfur-containing compounds such as sulfate, sulfite, $\mathrm{S}^{0}$, sulfide, cysteine, or methionine.

Isolate $\mathrm{K} 1$ grew well between 70 and $97^{\circ} \mathrm{C}$, and cell division still occurred at $100^{\circ} \mathrm{C}$. No growth was observed at 68 or $102^{\circ} \mathrm{C}$. The optimum growth temperature was 90 to $95^{\circ} \mathrm{C}$, with a doubling time of $200 \mathrm{~min}$ (Fig. 4). The optimum $\mathrm{pH}$ for growth was around 7.0. Growth was obtained in a $\mathrm{pH}$ range from 5.0 to 9.0 (Fig. 5). Metabolism of the medium components did not cause the initial medium $\mathrm{pH}$ to change significantly during these experiments (data not shown). The optimum salinity in the medium was found to be approximately $3.5 \%$, which was the same level of ionic strength as JXT medium (Fig. 6). Growth was observed at a salinity from 1.8 to $7.0 \%$. At a salinity of $1.5 \%$ in the medium, rapid cell lysis occurred, as indicated by the presence of ghost cells upon electron microscopic examination and by the decreased turbidity of the culture.

Sensitivity to antibiotics. Isolate K1 was insensitive to 100 $\mu \mathrm{g} / \mathrm{ml}$ concentrations of ampicillin, vancomycin, and cycloserine but was completely inhibited in the presence of the same concentration of chloramphenicol.

Lipids. The 2D-TLC pattern of the total lipid of isolate $\mathrm{K} 1$ appeared to be different from those of the archaeal total lipids investigated to date. At least five polar lipids were detected. Among these five polar lipids, one phosphoglycolipid (designated as AGI) and one phospholipid (designated as AI) were predominant. Assuming that each lipid contains one phosphate moiety, the content of AGI and AI in the total lipid was $91 \mathrm{~mol} \%$ and $9 \mathrm{~mol} \%$, respectively. The other three polar lipids (one phosphoglycolipid and two glycolipids) were present at trace levels.

The hydrocarbon chain prepared from the core lipid was identified by gas chromatography-mass spectrometry as $\mathrm{C}_{25}$ isoprenoid, and the structure of the glycerol diether core lipid was identified as disesterterpanyl $\left(\mathrm{C}_{25}, \mathrm{C}_{25}\right)$ glycerol. AGI contained glucose and inositol and AI contained inositol as polar head group components. Glycerophosphoinositol was detected as a sole phosphorus-containing product of the $\mathrm{BCl}_{3}$ treatment of AGI or AI. The complete structures of the polar lipids and their core portions will be published elsewhere.

DNA base composition. The genomic DNA of isolate $\mathrm{K} 1 \mathrm{had}$ a $\mathrm{G}+\mathrm{C}$ content of $67 \mathrm{~mol} \%$ as calculated by direct analysis of the nucleosides.

Phylogenetic analysis. The $\mathrm{G}+\mathrm{C}$ contents of the $16 \mathrm{~S}$ rRNA sequences employed in this analysis ranged from 62.7 to 68.7 $\mathrm{mol} \%$, and it was therefore assumed that they were relatively free from the variation of biased base compositions. Evolutionary distances were estimated by the comparison of representative archaeal 16S rRNA sequences. Isolate $\mathrm{K} 1$ presented considerably close relationships to Pyrodictium occultum and Desulfurococcus mobilis as indicated by estimated exchanges of 7.9 and 11.0 nucleotides per 100 positions, respectively.

A phylogenetic tree was inferred on the basis of these evolutionary distances by using the neighbor-joining method (Fig. 7). Isolate K1 represents a deep lineage within the Crenarchaeota. The cluster consisting of isolate $\mathrm{K} 1$, Pyrodictium occultum, and Desulfurococcus mobilis was specifically associated with Sulfolobus shibatae, with a $95 \%$ confidence in a bootstrap analysis of this tree on the basis of 100 resamplings. However, the branching of isolate K1 more deeply than Pyrodictium occultum or Desulfurococcus mobilis is given with a low level of confidence $(24 \%)$. The level might be increased by isolating and sequencing the $16 \mathrm{~S}$ rRNA of more species within the Crenarchaeota, a work which is currently under way in our laboratories.

Furthermore, this tree topology was contrasted to that inferred from transversion distances, since the effect of compo-

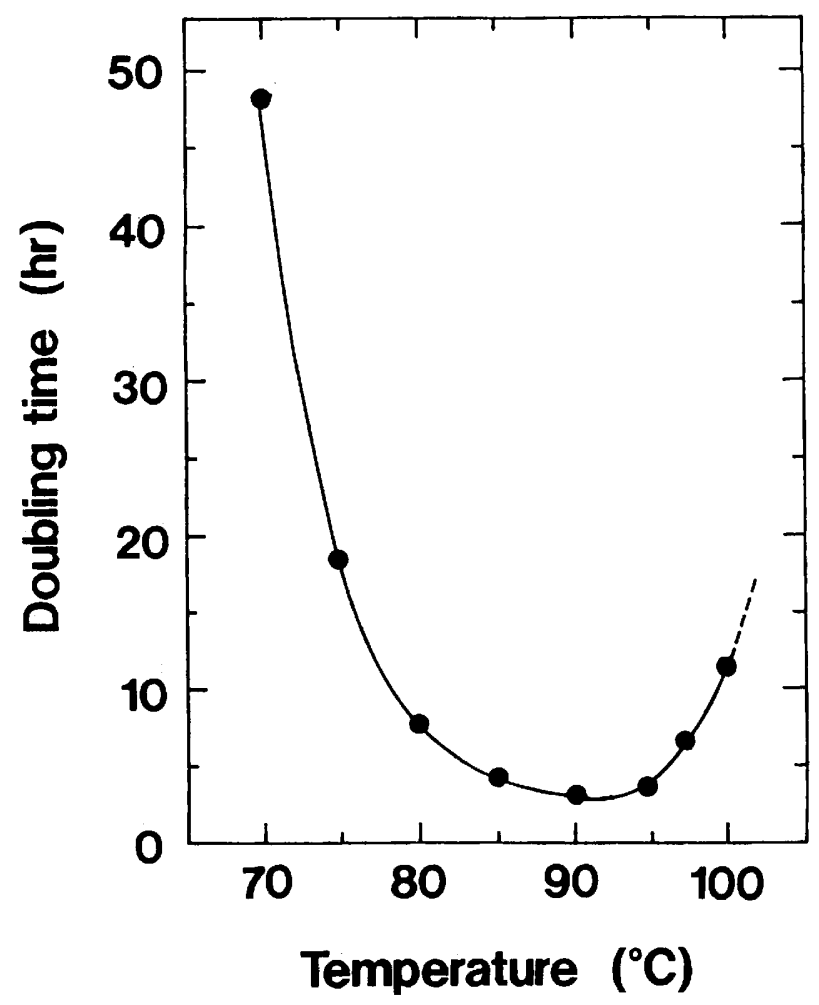

FIG. 4. Optimum growth temperature of Aeropyrum pernix K1. Doubling times were calculated from the slopes of the growth curves. 


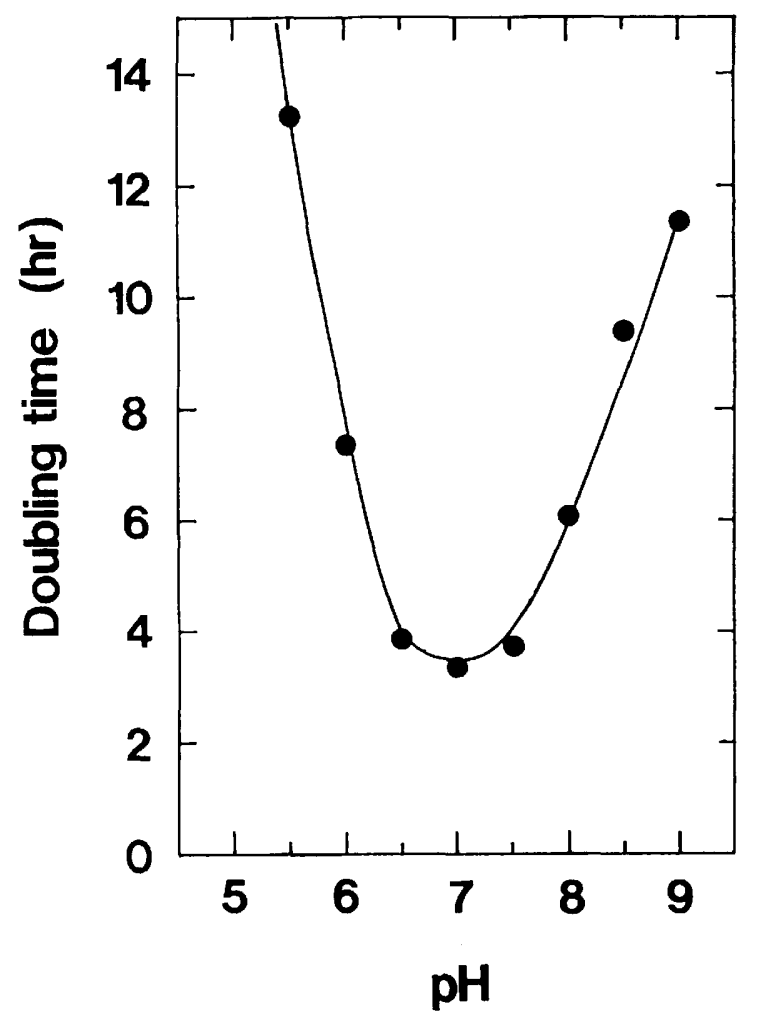

FIG. 5. Influence of $\mathrm{pH}$ on growth of Aeropyrum pernix K1. Doubling times were calculated as described in the legend to Fig. 4.

sitional bias can be mitigated by confining analysis to transversion substitution only (56). All sequences employed in this analysis have purine contents in the range of 56.1 to $57.2 \%$. The resulting tree derived by transversion distance analysis also gave the same topology as that in Fig. 7 (data not shown).

\section{DISCUSSION}

The novel marine isolate $\mathrm{K} 1$ represents the first strictly aerobic hyperthermoneutrophile growing optimally at temperatures above $90^{\circ} \mathrm{C}$. On account of the presence of isopranyl ether lipids and its 16S rRNA sequence, the isolate belongs to the phylogenetic domain of the Archaea $(11,23,54)$. In addition, its insensitivity to inhibitors of peptidoglycan synthesis such as ampicillin, vancomycin, and cycloserine provides further support that isolate $\mathrm{K} 1$ is a member of the Archaea (15, 24).

Isolate $\mathrm{K} 1$ does not fit into any of the described taxa within the Archaea domain. In particular, on the basis of its hyperthermophily and strict aerophily, isolate $\mathrm{K} 1$ is distinct from other archaea. Several members within the orders Sulfolobales and Thermoplasmales are able to grow aerobically, depending on the culture conditions. Sulfolobus spp. have an irregular coccoid shape and are capable of growing under aerobic conditions, either heterotrophically, or by the oxidation of $S^{0}(41)$, chemolithoautotrophically. Among them, Sulfolobus solfataricus DSM1616 ${ }^{\mathrm{T}}$ grows optimally at $87^{\circ} \mathrm{C}(61)$. Acidianus spp. and Desulfurolobus spp. are facultatively aerobic $S^{0}$ oxidizers $(42,62)$. Metallosphaera sedula is strictly an aerobe, either by heterotrophy or chemolithoautotrophy (18). Thermoplasma spp. are facultative aerobes (25). However, all of them have distinctly lower $\mathrm{G}+\mathrm{C}$ contents, which range from 31 to 46 mol\%, and grow optimally below $\mathrm{pH} 4.0$, whereas isolate $\mathrm{K} 1$ has a $\mathrm{G}+\mathrm{C}$ content of $67 \mathrm{~mol} \%$ and grows within a $\mathrm{pH}$ range from 5.0 to 9.0. Furthermore, the other genera within the Archaea domain consist of obligate anaerobes.

Besides its unusual phenotypes described above, isolate $\mathrm{K} 1$ possesses unique physiological properties. Cultures of isolate K1 grow very rapidly, with a doubling time of about $200 \mathrm{~min}$. This feature of rapid growth should make it an attractive organism for basic studies of aerobic hyperthermophiles, and gram quantities of cells can be obtained easily in 2 days. In this connection, it was observed that thiosulfate greatly increased cell yields without $\mathrm{H}_{2} \mathrm{~S}$ production. We have also demonstrated thiosulfate-oxidizing activity in cell-free extracts of isolate $\mathrm{K} 1$ (35). These results suggest that isolate $\mathrm{K} 1$ has a highly developed thiosulfate-oxidizing system for energy generation. Similar to this, thiosulfate-oxidizing heterotrophs have been found in fresh water $(48,52)$ and in a variety of marine habitats (49-51).

Isolate $\mathrm{K} 1$ contains lipids which for hyperthermophilic archaea are novel. Generally, most sulfur-dependent, thermophilic members of the Archaea domain such as Sulfolobus spp., Thermoplasma spp., and several species within the order Thermoproteales contain a caldarchaeol core along with a trace amount of archaeol, except Thermococcus celer, which has only an archaeol core (13). In contrast, the core lipid of isolate K1 consists only of archaeol. A similar core lipid is so far only known from the alkaliphilic halophile Natronobacterium SP8, but its content is only 1 to $6 \%$ (12). Besides its core lipid structure, the lipid composition of isolate $\mathrm{K} 1$ is also unique. Only one phosphoglycolipid (AGI) is predominant. AGI seems

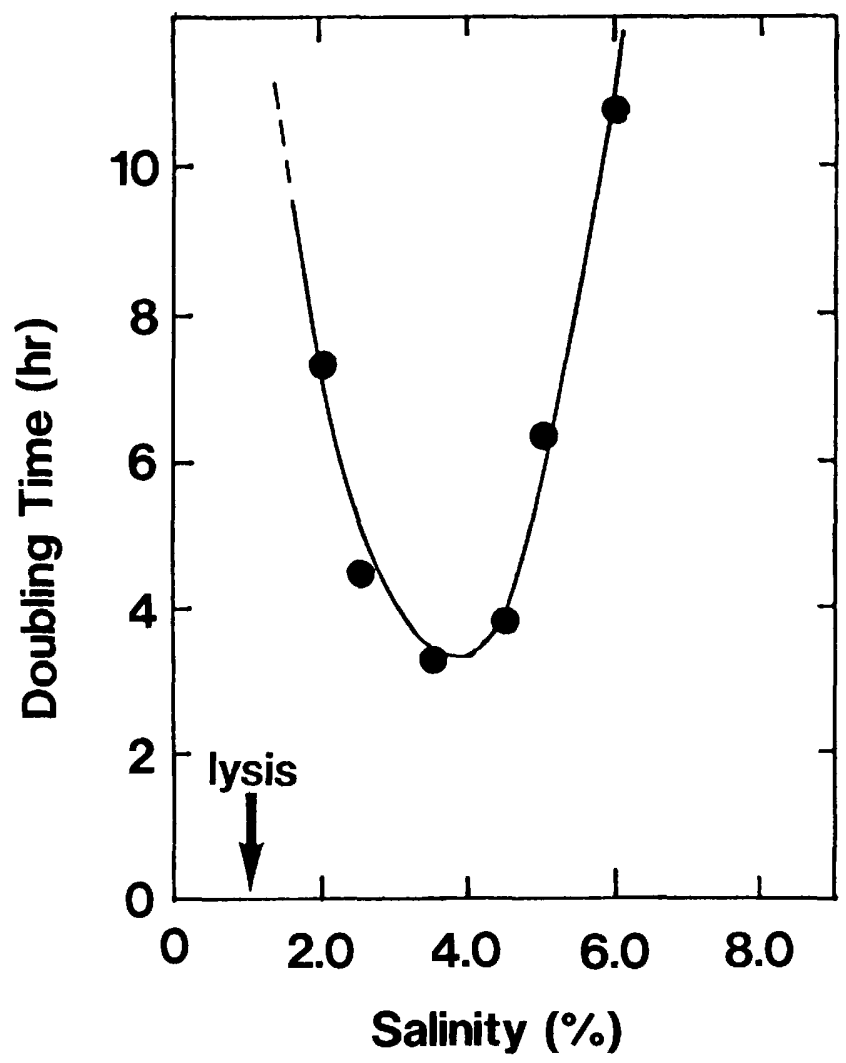

FIG. 6. Effect of salinity on growth of Aeropyrum pernix K1. Doubling times were calculated as described in the legend to Fig. 4. 


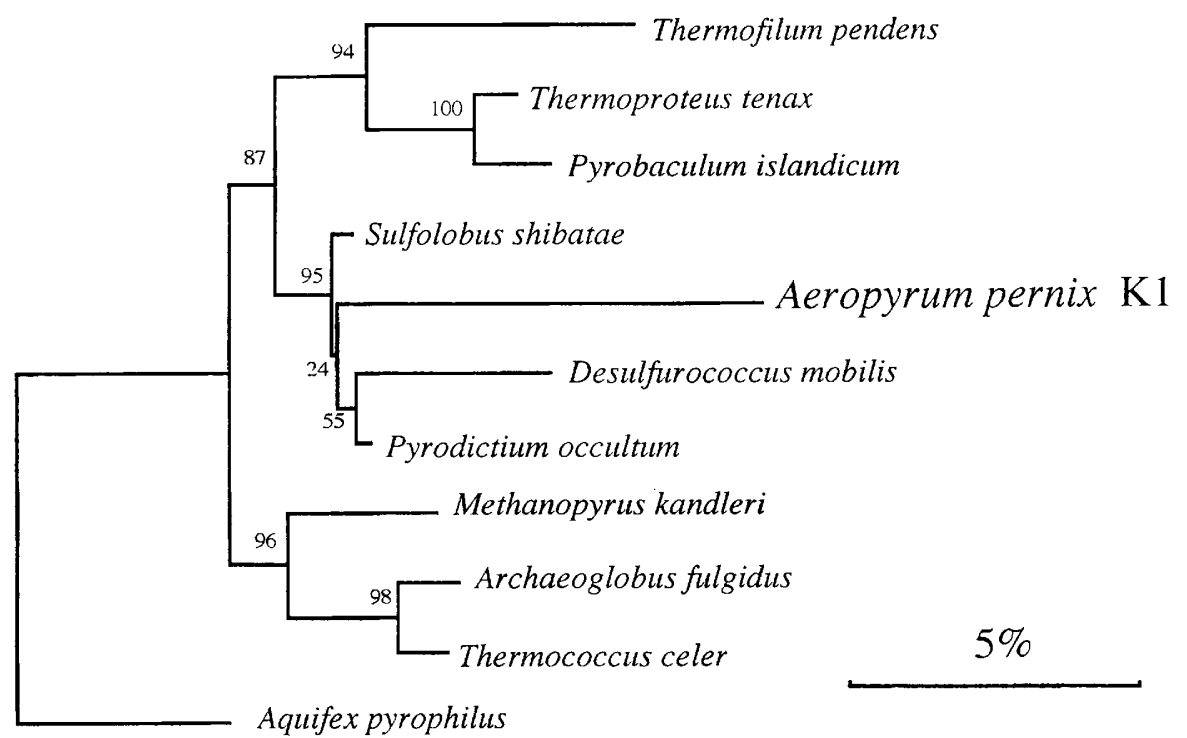

FIG. 7. Phylogenetic position of Aeropyrum permix K1 within the representative archaea inferred from the 16S rRNA evolutionary distances. Scale bar indicates 5 substitutions per hundred nucleotides. Numbers represent bootstrap values. Nucleotide sequence accession numbers employed in the phylogenetic analysis are as follows: Aquifex pyrophilus, M83548; Archaeoglobus fulgidus, Y00275; Desulfurococcus mobilis, M36474; Methanopyrus kandleri, M59932; Pyrobaculum islandicum, L07511; Pyrodictium occultum, M21087; Sulfolobus shibatae, M32504; Thermococcus celer, M21529; Thermofilum pendens, X14835; Thermoproteus tenax, M35966.

to be a novel diether phosphoglycolipid, which contains both glucose and inositol.

The phylogenetic analysis based on 16S rRNA sequence indicates that isolate $\mathrm{K} 1$ is related to the genera Pyrodictium and Desulfurococcus within the Crearchaeota. However, isolate K1 may be assigned a separate genus, since (i) the evolutionary distances between isolate $\mathrm{K} 1$ and each of these two archaeal genera (7.9 and 11.0 substitutions per 100 nucleotides, respectively) is significantly higher than that between Pyrobaculum islandicum and Thermoproteus tenax (2.0 substitutions), each of which belongs to different archaeal genera, and (ii) $P$. occultum and $D$. mobilis are unable to grow in aerobic conditions $(44,60)$.

The phylogenetic depth of isolate K1 within the Archaea domain raises problems about the origin and evolution of oxygen respiration on the Earth. In the traditional view, the Earth's archaean atmosphere has been presumed to be highly reducing (22), and aerobic organisms are presumed to have evolved after oxygenic photosynthetic organisms became active. In contrast, Towe suggested that the archaean atmosphere contained a low $(0.2$ to $0.4 \%)$ but stable proportion of oxygen as a component of the global carbon cycle (46). Furthermore, based on sulfur isotope analyses of microscopicsized grains of pyrite, it is likely that sulfur-reducing organisms converted seawater sulfate into pyrites at least 3.4 billion years ago (35). This observation implies that by about 3.4 billion years ago the oceans were rich in sulfate and the atmosphere contained appreciable amounts of free oxygen. Interestingly, Aquifex pyrophilus and Pyrobaculum aerophilum, which represent the deep and short lineages within the Bacteria and Archaea domains, respectively, are able to grow in microaerophilic conditions $(21,53)$. It is still unclear when the oxygen respirating metabolism was acquired and how it was developed, but the origin of aerobic organisms might be more ancient than is commonly believed. Further study of the aerobic respiration of isolate $\mathrm{K} 1$ could elucidate these issues.

The ecological distribution of this new organism is at present unknown. Isolate $\mathrm{K} 1$ was obtained from a geothermally heated marine solfataric biotope on a seashore of Kodakara-Jima
Island, Kagoshima, Japan. The inability of isolate K1 to grow appreciably at the expense of sulfide is puzzling in light of the abundance of sulfide at this site, but it could actually be a reflection of the unusual growth conditions this organism experiences in situ. We have been able to isolate close relatives of isolate $\mathrm{K} 1$ from a shallow submarine hydrothermal vent in Tachibana Bay, Nagasaki, Japan $\left(32^{\circ} 45^{\prime} \mathrm{N}, 130^{\circ} 10^{\prime} \mathrm{E}\right)(37)$. There would seem to be several ways that geothermally heated water could contain, or become contaminated with, oxygen in these hydrothermal environments. Therefore, isolate $\mathrm{K} 1$ and its relatives may thrive in widespread oxidative zones within marine hydrothermal environments.

On the basis of the strictly aerobic mode of life, a distinct $\mathrm{G}+\mathrm{C}$ content of $67 \mathrm{~mol} \%$, the idiosyncratic lipid composition, and the low level of similarity of the 16S rRNA sequence with any member of the Archaea, we describe here the new genus Aeropyrum; Aeropyrum pernix is the type species of this genus, and strain K1 (= JCM 9820) is the type strain of Aeropyrum pernix.

Description of Aeropyrum gen. nov. Aeropyrum (Ae.ro.py' rum. Gr. n. aer air; Gr. neutr. n. pyr fire; M.L. masc. n. Aeropyrum air fire, referring to the hyperthermophilic respirative character of the organism). Cells stain gram negative and are coccoid and highly irregular in shape. Cells are usually about 0.8 to $1.0 \mu \mathrm{m}$ in diameter. Motile cells are surrounded by a cell envelope covering the cytoplasmic membrane. Strictly aerobic, heterotrophic, hyperthermoneutrophiles. Growth occurs between 70 and $100^{\circ} \mathrm{C}$ (optimum, 90 to $95^{\circ} \mathrm{C}$ ), at $\mathrm{pH} 5$ to 9 (optimum, $\mathrm{pH}$ 7.0 ), and at 1.8 to $7.0 \%$ salinity (optimum, $3.5 \%$ salinity). Cells are insensitive to ampicillin, vancomycin, and cycloserine and sensitive to chloramphenicol. Only disesterterpanyl $\left(\mathrm{C}_{25}, \mathrm{C}_{25}\right)$ glycerol ether lipids in the cell membrane. No fatty acid is detected. Genomic DNA has a $\mathrm{G}+\mathrm{C}$ content of about 67 mol\%. On the basis of $16 \mathrm{~S}$ rRNA analysis, the genus Aeropyrum does not belong to any of the taxa known so far and represents one of the deepest phylogenetic lineages within the Archaea domain. Members of the genus Aeropyrum occur in neutral to slightly alkaline boiling solfataric sediments and 
waters in marine environments. The type species is Aeropyrum pernix.

Description of Aeropyrum pernix sp. nov. Aeropyrum pernix (per'nix. L. adj. pernix nimble). Cells are gram negative and irregular coccoid. Cells are usually about 0.8 to $1.0 \mu \mathrm{m}$ in diameter. Vigorous motility is evident by light microscopy either at room temperature or at $90^{\circ} \mathrm{C}$. Cells frequently have pili-like appendages. The envelope surrounding the cells is about 25 nm wide. Packed cells are brown. Strictly aerobic, heterotrophic, hyperthermoneutrophiles. Growth occurs between 70 and $100^{\circ} \mathrm{C}$ (optimum, 90 to $95^{\circ} \mathrm{C}$ ), at $\mathrm{pH} 5$ to 9 (optimum, $\mathrm{pH}$ 7.0 ), and at 1.8 to $7.0 \%$ salinity (optimum, $3.5 \%$ salinity). No growth is detected at 68 or $102^{\circ} \mathrm{C}$. Cells lyse by low osmotic shock (below $1.5 \%$ salinity). Thiosulfate stimulates growth. Oxygen serves as a possible electron acceptor. During growth, $\mathrm{H}_{2} \mathrm{~S}$ is not produced in either the presence or absence of thiosulfate. The core lipids consist solely of disesterterpanyl $\left(\mathbf{C}_{25}\right.$, $\mathrm{C}_{25}$ ) glycerol ether lipids. The polar lipids consist of five components, but only phosphoglycolipid (AGI; 91\%) (containing inositol and glucose) and phospholipid (AI; 9\%) are predominant. Genomic DNA has a $\mathrm{G}+\mathrm{C}$ content of $67 \mathrm{~mol} \%$. By $16 \mathrm{~S}$ rRNA sequence comparisons, the evolutionary distances (estimated changes per 100 nucleotides) from $P$. occultum and $D$. mobilis are 7.9 and 11.0 , respectively. Isolate was obtained from hot sedimentary materials and venting waters at a coastal solfataric vent in Kodakara-Jima Island, Japan. The type strain is Aeropyrum pernix K1, JCM 9820, Japan Collection of Microorganisms, The Institute of Physical and Chemical Research (RIKEN), Wako-shi, Saitama, Japan.

\section{ACKNOWLEDGMENTS}

We thank the crew of the research vessel Sogen-maru for collecting samples. We are grateful to Iwao Furusawa (Kyoto University, Japan) and Tadaaki Yoshida (Kureha Chemical Industry Co. Ltd., Japan) for electron microscopy.

This work was supported in part by a Grant-in-Aid for Scientific Research (no. 07556048 and 5405) from the Ministry of Education, Science and Culture of Japan. Norimichi Nomura was supported by the Research Fellowship of the Japan Society for the Promotion of Science for Young Scientists.

\section{REFERENCES}

1. Achenbach-Richter, L., R. Gupta, K. O. Stetter, and C. R. Woese. 1987. Were the original eubacteria thermophiles? Syst. Appl. Microbiol. 9:34-39.

2. Achenbach-Richter, L., R. Gupta, W. Zillig, and C. R. Woese. 1988. Rooting the archaebacterial tree: the pivotal role of Thermococcus celer in archaebacterial evolution. Syst. Appl. Microbiol. 10:231-240.

3. Achenbach-Richter, L., K. O. Stetter, and C. R. Woese. 1987. A possible biochemical missing link among archaebacteria. Nature (London) 327:348349.

4. Balch, W. E., and R. S. Wolfe. 1976. New approach to the cultivation of methanogenic bacteria: 2-mercaptoethanesulfonic acid (HS-CoM)-dependent growth of Methanobacterium numinantium in a pressurized atmosphere. Appl. Environ. Microbiol. 32:781-791.

5. Baross, J. A. 1995. Isolation, growth, and maintenance of hyperthermophiles, p. 15-23. In F. T. Robb and A. R. Place (ed.), Archaea, a laboratory manual, thermophiles. Cold Spring Harbor Laboratory, Cold Spring Harbor, N.Y.

6. Bartlett, G. R. 1959. Phosphorus assay in column chromatography. J. Biol. Chem. 234:466-468.

7. Baumeister, W., and G. Lembcke. 1992. Structural features of archaebacterial cell envelopes. J. Bioenerg. Biomembr. 24:567-575.

8. Bligh, E. G., and W. J. Dyer. 1959. A rapid method of total lipid extraction and purification. Can. J. Biochem. Physiol. 37:911-917.

9. Cavalier-Smith, T. 1992. Bacteria and eukaryotes. Nature (London) 356:570.

10. DeLong, E. F. 1992. Archaea in coastal marine environments. Proc. Natl. Acad. Sci. USA 89:5685-5689.

11. De Rosa, M., and A. Gambacorta. 1988. The lipids of archaebacteria. Prog. Lipid Res. 27:153-157.

12. De Rosa, M., A. Gambacorta, B. Nicolaus, and W. D. Grant. 1983. A C $25, C_{25}$ diether core lipid from archaebacterial haloalkaliphiles. J. Gen. Microbiol. 129:2333-2337.
13. De Rosa, M., A. Gambacorta, A. Trincone, A. Basso, W. Zillig, and I. Holz. 1987. Lipids of Thermococcus celer, a sulfur-reducing archaebacterium: structure and biosynthesis. Syst. Appl. Microbiol. 9:1-5.

14. Felsenstein, J. 1985. Confidence limits on phylogenies: an approach using bootstrap. Evolution 39:783-791.

15. Hilpert, R., J. Winter, W. Hammes, and O. Kandler. 1981. The sensitivity of archaebacteria to antibiotics. Zentralbl. Bakteriol. Parasitenkd. Infektionskr. Hyg. Abt. 1 Orig. Reihe C 2:11-20.

16. Hoaki, T., M. Nishijima, M. Kato, K. Adachi, S. Mizobuchi, N. Hanzawa, and T. Maruyama. 1994. Growth requirements of hyperthermophilic sulfurdependent heterotrophicarchaea isolated from a shallow submarine geothermal system with reference to their essential amino acids. Appl. Environ. Microbiol. 60:2898-2904.

17. Hoaki, T., M. Nishijima, H. Miyashita, and T. Maruyama. 1995. Dense community of hyperthermophilic sulfur-dependent heterotrophs in a geothermally heated shallow submarine biotope near Kodakara-Jima Island, Kagoshima, Japan. Appl. Environ. Microbiol. 61:1931-1937.

18. Huber, G., C. Spinnler, A. Gambacorta, and K. O. Stetter. 1989. Metallospaera sedula gen. and sp. nov. represents a new genus of aerobic, metalmobilizing, thermoacidophilic archaebacteria. Syst. Appl. Microbiol. 12:3847.

19. Huber, R., T. A. Langworthy, H. Konig, M. Thomm, C. R. Woese, U. B. Sleytr, and K. O. Stetter. 1986. Thermotoga maritima sp. nov. represents a new genus of unique extremely thermophilic eubacteria growing up to $90^{\circ} \mathrm{C}$. Arch. Microbiol. 144:324-333.

20. Huber, R., P. Stoffers, J. L. Cheminee, H. H. Richnow, and K. O. Stetter. 1990. Hyperthermophilic archaebacteria within the crater and open-sea plume of erupting Macdonald Seamount. Nature (London) 345:179-182.

21. Huber, R., T. Wilharm, D. Huber, A. Trincone, S. Burggraf, H. Konig, R. Rachel, I. Rockinger, H. Fricke, and K. O. Stetter. 1992. Aquifex pyrophilus gen. nov. represents a novel group of marine hyperthermophilic hydrogenoxidizing bacteria. Syst. Appl. Microbiol. 15:340-351.

22. Kasting, J. F. 1987. Theoretical constraints on oxygen and carbon dioxide concentrations in the Precambrian atmosphere. Precambrian Res. 34:205229.

23. Koga, Y., M. Nishihara, H. Morii, and M. Akagawa-Matsushita. 1993. Ether polar lipids of methanogenic bacteria: structures, comparative aspects, and biosyntheses. Microbiol. Rev. 57:164-182.

24. Konig, H., and K. O. Stetter. Archaeobacteria, p. 2171-2173. In J. T. Staley, M. P. Bryant, N. Pfennig, and J. G. Holt (ed.), Bergey's manual of systematic bacteriology, vol. 3. The Williams \& Wilkins Co., Baltimore.

25. Langworthy, T. A., and P. F. Smith. 1989. Cell wall-less archaebacteria, p. 2233-2236. In J. T. Staley, M. P. Bryant, N. Pfennig, and J. G. Holt (ed.), Bergey's manual of systematic bacteriology, vol. 3. The Williams \& Wilkins Co., Baltimore.

26. Marmur, J., and P. Doty. 1962. Determination of the base composition of deoxyribonucleic acid from its thermal denaturation temperature. J. Mol. Biol. 5:109-118.

27. Mesbah, M., U. Premachandran, and W. B. Whitman. 1989. Precise measurement of the $\mathrm{G}+\mathrm{C}$ content of deoxyribonucleic acid by high-performance liquid chromatography. Int. J. Syst. Bacteriol. 39:159-167.

28. Morikawa, M., Y. Izawa, N. Rashid, T. Hoaki, and T. Imanaka. 1994. Purification and characterization of a thermostable thiol protease from a newly isolated hyperthermophilic Pyrococcus sp. Appl. Environ. Microbiol. 60: 4559-4566.

29. Murray, M. G., and W. F. Thompson. 1980. Rapid isolation of high molecular-weight plant DNA. Nucleic Acids Res. 8:4321-4325.

30. Nishihara, M., H. Morii, and Y. Koga. 1987. Structure determination of a quartet of novel tetraether lipids from Methanobacterium thermoautotrophicum. J. Biochem. 101:1007-1015.

31. Nishihara, M., H. Morii, and Y. Koga. 1989. Heptads of polar ether lipids of an archaebacterium, Methanobacterium thermoautotrophicum: structure and biosynthetic relationship. Biochemistry 28:95-102.

32. Nishihara, M., and Y. Koga. 1988. Quantitative conversion of diether or tetraether phospholipids to glycerophosphoesters by dealkylation with boron trichloride: a tool for structural analysis of archaebacterial lipids. J. Lipid Res. 29:384-388.

33. Nishihara, M., and Y. Koga. 1991. Hydroxyarchaetidylserine and hydroxyarchaetidyl-myo-inositol in Methanosarcina barkeri: polar lipids with a new ether core portion. Biochim. Biophys. Acta 1082:211-217.

34. Nomura, N., and Y. Sako. Unpublished data.

35. Ohmoto, H., T. Kanegawa, and D. R. Lowe. 1993. 3.4-billion-year-old biogenic pyrites from Barberton, South Africa: sulfur isotope evidence. Science 262:555-557.

36. Saitou, N., and M. Nei. 1987. The neighbor-joining method: a new method for reconstructing phylogenetic trees. Mol. Biol. Evol. 4:406-425.

37. Sako, Y., T. Kogishi, N. Nomura, and Y. Ishida. Unpublished data.

38. Sambrook, J., E. F. Fritsch, and T. Maniatis. 1989. Molecular cloning: a laboratory manual, 2nd ed., p. 9.14-9.23. Cold Spring Harbor Laboratory, Cold Spring Harbor, N.Y.

39. Sanger, F., A. R. Coulson, G. F. Hong, O. F. Hill, and G. B. Petersen. 1982. Nucleotide sequence of bacteriophage $\lambda$ DNA. J. Mol. Biol. 162:729-773. 
40. Sanger, F., S. Nicklen, and A. R. Coulson. 1977. DNA sequencing with chain-terminating inhibitors. Proc. Natl. Acad. Sci. USA 74:5463-5467.

41. Segerer, A., and K. O. Stetter. 1989. Genus I. Sulfolobus Brock, Brock, Belly and Weiss $1972,66^{\mathrm{AL}}$, p. $2250-2251$. In J. T. Staley, M. P. Bryant, N. Pfennig, and J. G. Holt (ed.), Bergey's manual of systematic bacteriology, vol. 3. The Williams \& Wilkins Co., Baltimore.

42. Segerer, A., and K. O. Stetter. 1989. Genus II. Acidianus Segerer, Neuner, Kristjansson and Stetter 1986, 562 $2^{\mathrm{vp}}$, p. 2251-2253. In J. T. Staley, M. P. Bryant, N. Pfennig, and J. G. Holt (ed.), Bergey's manual of systematic bacteriology, vol. 3. The Williams \& Wilkins Co., Baltimore.

43. Stetter, K. O., G. Fiala, G. Huber, R. Huber, and A. Segerer. 1990. Hyperthermophilic microorganisms. FEMS Microbiol. Rev. 75:117-124.

44. Stetter, K. O., H. König, and E. Stackebrandt. 1983. Pyrodictium gen. nov., a new genus of submarine disc-shaped sulphur reducing archaebacteria growing optimally at $105^{\circ} \mathrm{C}$. Syst. Appl. Microbiol. 4:535-551.

45. Tajima, F., and M. Nei. 1984. Estimation of evolutionary distance between nucleotide sequences. Mol. Biol. Evol. 1:269-285.

46. Towe, K. M. 1990. Aerobic respiration in the Archaean? Nature (London). 348:54-56.

47. Traub, S., S. Mizushima, C. V. Lowry, and M. Nomura. 1971. Reconstitution of ribosomes from subribosomal components. Methods Enzymol. 20:391-407.

48. Tuttle, J. H. 1980. Thiosulfate oxidation and tetrathionate reduction by intact cells of marine pseudomonad 16B. Appl. Environ. Microbiol. 39:11591166.

49. Tuttle, J. H., and H. W. Jannasch. 1972. Occurrence and types of Thiobacillus-like bacteria in the sea. Limnol. Oceanogr. 17:532-543.

50. Tuttle, J. H., and H. W. Jannasch. 1973. Sulfide and thiosulfate-oxidizing bacteria in anoxic marine basins. Mar. Biol. 20:64-70.

51. Tuttle, J. H., and H. W. Jannasch. 1977. Thiosulfate stimulation of microbial dark assimilation of carbon dioxide in shallow marine waters. Microb. Ecol. 4:9-25.

52. Veinstein, M. B. 1976. On taxonomy of Thiobacillus trautweinii. Microbiologiya 45:137-141.
53. Volkel, P., R. Huber, E. Drobner, R. Rachel, S. Burggraf, A. Trincone, and K. O. Stetter. 1993. Pyrobaculum aerophilum sp. nov., a novel nitrate-reducing hyperthermophilic archaeum. Appl. Environ. Microbiol. 59:2918-2926.

54. Winker, S., and C. R. Woese. 1991. A definition of the domains Archaea, Bacteria, and Eucarya in terms of small subunit ribosomal RNA characteristics. Syst. Appl. Microbiol. 14:305-310.

55. Woese, C. R. 1987. Bacterial evolution. Microbiol. Rev, 51:221-271.

56. Woese, C. R., L. Achenbach, P. Rouviere, and L. Mandelco. 1991. Archaeal phylogeny: reexamination of the phylogenetic position of Archaeoglobus fulgidus in light of certain composition-induced artifacts. Syst. Appl. Microbiol. 14:364-371.

57. Woese, C. R., and G. E. Fox. 1977. Phylogenetic structure of the prokaryotic domain: the primary kingdoms. Proc. Natl. Acad. Sci. USA 74:5088-5090.

58. Woese, C. R., O. Kandler, and M. L. Wheelis. 1990. Towards a natural system of organisms: proposal for the domains Archaea, Bacteria, and Eucarya. Proc. Natl. Acad. Sci. USA 87:4576-4579.

59. Zillig, W., I. Holz, D. Janekovic, H.-P. Klenk, E. Imsel, J. Trent, S. Wunderl, V. H. Forjaz, R. Coutinho, and T. Ferreira. 1990. Hyperthermus butylicus, a hyperthermophilic sulfur-reducing archaebacterium that ferments peptides. J. Bacteriol. 172:3959-3965.

60. Zillig, W., K. O. Stetter, D. Prangishvilli, W. Schafer, S. WunderI, D. Janekovic, I. Holz, and P. Palm. 1982. Desulfurococcaceae, the second family of the extremely thermophilic, anaerobic, sulfur-respiring Thermoproteales. Zentralbl. Bakteriol. Parasitenkd. Infektionskr. Hyg. Abt. 1 Orig. Reihe C 3:304 317.

61. Zillig, W., K. O. Stetter, S. Wunderl, W. Schulz, H. Priess, and I. Scholz. 1980. The Sulfolobus-"Caldariella" group: taxonomy on the basis of the structure of DNA-dependent RNA polymerases. Arch. Microbiol. 125:259 269.

62. Zillig, W., S. Yeats, I. Holz, A. Bock, M. Rettenberger, F. Gropp, and G. Simon. 1986. Desulfurolobus ambivalens, gen. nov., sp. nov., an autotrophic archaebacterium facultatively oxidizing or reducing sulfur. Syst. Appl. Microbiol. 8:197-203. 